\author{
Sidey Myoo \\ ๑i https://orcid.org /0000-0001-6163-4742 \\ Department of Aesthetics, Institute of Philosophy \\ Jagiellonian University \\ michal.ostrowicki@uj.edu.pl
}

\title{
THE COMMONPLACE OF MAN IN THE TIMES OF ANTHRO- POMORPHIC AND INTELLIGENT ROBOTS
}

\begin{abstract}
Imitation is natural to man from childhood, one of his advantages over the lower animals being this, that he is the most imitative creature in the world, and learns at first by imitation.
\end{abstract}

Aristotle, Poetics ${ }^{1}$

\begin{abstract}
The objective of this paper is to discuss the commonplace of man in relation to the theory of mimesis in the context of the analysis of current examples of anthropomorphic and intelligent robots. Two aspects of the analysis have been taken into consideration. The first one is linked with the similarities of such robots to the idealized human body and the second one acknowledges mental similarities between the robots and humans, which entail the question of artificial intelligence. Most of the quoted examples derive from the world of art which has become an interdisciplinary area of collaboration between artists and engineers. This contribution contains a comparative study and a part of it, in many cases, involves the contributor's observations on the presented intelligent robots.
\end{abstract}

Keywords: commonplace of man, anthropomorphic robot, an ideal of corporeality, artificial intelligence, new media art

1 Aristotle, Poetics, trans. Ingram Bywater, Oxford Press 1962, p. 4. 
The need to build a humanlike creature with such human traits as a beautiful body is intriguing and hardly understandable, though it has existed for centuries. The ancient concept is currently being interpreted anew in an interesting way with reference to reframing the idea of anthropomorphic and intelligent robots. Modern technology allows us to build idealised robots with human traits that affect people in beneficial and evident ways. The use of better and better materials, and engineering solutions leads to more effective experiences of a human coming into contact with intelligent and anthropomorphic robots whose number is still increasing as they become increasingly advanced. ${ }^{2}$ In ancient Greece, philosophers and artists searched for the ideal body in the form of marble sculptures created with the canons of beauty, and we may ponder what effects we can expect from modern discoveries linking art, science and technology. Additionally, artificial intelligence allows us to have an uninterrupted conversation which increases our expectations of the artificial man in comparison with what was possible in the past, because it includes another aspect of the human, i.e. their psyche, which supplements their ideal of a body.

A modern search for the ideal of man requires the collaboration of artists, engineers, psychologists and/or philosophers. Owing to such an interdisciplinary approach, you may define the commonplace of man in many dimensions, taking into account its many traits, which may lead to showing the evolution of everlasting aspirations in the form of a mimetic reflection of the varieties of human nature. The realisation of those expectations by robots has been evolving rapidly owing to the development of technology, so it is hardly possible that something could stop this process. However, advanced mimetic features linked with the extrapolation of some human personality characteristics found in robots may incite dilemmas about the human who is modelled in that manner.

The case of anthropomorphic and intelligent robots evokes interesting questions because of mimetism involving not only the physical body, but also the human psyche. Those questions arise from the development of artificial intelligence which, in turn, is related to the phenomena of linguistic expression and semantics, as well as programmed empathy. Research outcomes show that "Anthropomorphism describes the tendency to imbue the real or imagined behaviour of nonhuman agents with humanlike characteristics, motivations, intentions, or emotions." 3 Among those types of robots, you may find art bots

2 Websites with content regarding artificial intelligence and intelligent robots: AIArtists.org: https://aiartists.org/, SingularityHub: https://singularityhub.com/2019/06/17/the-rise-of-ai-art-and-what-it-means-for-human-creativity/, EngineeredArts: https://www.engineeredarts. co.uk/, CloudPainter: http://www.cloudpainter.com/

3 N. Epley, A. Waytz, J. Cacioppo, On seeing human: a three-factor theory of anthropomorphism, "Psychological Review”, Vol. 114 (4), 2007, p. 864, doi: 10.1037/0033-295X.114.4.864 
which can create art, which could increase interest in these issues because of a wider debate on the creativity of artificial intelligence. ${ }^{4}$ My point is to focus on the question of the form of the body and mental behaviours of anthropomorphic robots, interpreted as modern reframing of historical human aspirations. ${ }^{5}$ This analysis is to reveal that the idealisation of the human body and natural behaviours may establish a noteworthy alternative to inter-human relations.

"Anthropomorphism may be necessary for robots to appear socially capable, but also to enable them to move around in a world built for the human body. However, should a socially assistive robot be built to appear more anthropomorphic than its capabilities, disappointment may arise as soon as expectations are not met." 6

Such robots may be suitably developed and adjusted to the professional and/or emotional needs. Thus, a question may arise whether such an ideal may substitute a human in "flesh". It triggers a wider debate on the values of interhuman relations which are treated as unique and irreplaceable or, in contrast, sometimes so difficult that we prefer contacts with specially designed intelligent robots. Various components - masculine, feminine or androgenic - could adopt specific traits of character and/or gender, and personalities which could help them establish a harmonious relationship with a given human. You could hardly deny the value of the developed character which, in turn, could self-learn and improve in the process of interaction with the human partner, adapting to their emotional needs. Additionally, the rapid evolution of technology indicates that such beings shall be developed and become more and more advanced, which may result in creating a seductive alternative to traditional relationships and starting new types of them.

It is worth mentioning a multi-year project which was started in 2008 by an artist and engineer Hiroshi Ishiguro, who called it Geminoids ${ }^{7}$ (Latin:

4 This paper does not deal with the nature of the creative process or, more specifically, the possibility of art creation in the case of intelligent robots and software. This question was discussed in the paper Creative Robots, published in Nataša Janković, Boško Drobnjak and Marko Nikolić (eds.), "Proceedings of the 21st International Congress of Aesthetics, Possible Worlds of Contemporary Aesthetics: Aesthetics Between History, Geography and Media”, University of Belgrad, Belgrad 2019, pp. 1145-1149: http://www.sideymyoo.art.pl/ wp-content/uploads/2019/11/Sidey-Myoo_Creative-Robots.pdf

E. Wójtowicz, Writing Personalities. Art Vis-a-vis Artificial Intelligence - Ken Feingold's "Figures of Speech", in: R. Kluszczyński (ed.), Ken Feingold - Figures of Speech, "Art+Science Meeting”, Łaźnia Centre for Contemporary Art, Gdańsk 2014, pp. 76-107: https://www. academia.edu/19067518/Ken_Feingold_Figures_of_Speech_Ken_Feingold_Figury_mowy

6 L. Bishop, A. van Maris, S. Dogramadzi, N. Zook, Social robots: The influence of human and robot characteristics on acceptance, in: "Paladyn - Journal of Behavioral Robotics" Vol. 10/1, 2019, p. 349, DOI: https://doi.org/10.1515/pjbr-2019-0028

7 Websites on Geminoids created by H. Ishiguro: http://www.geminoid.jp/en/index.html 
a brother, a pair), widely renowned Sophie (2016) who aroused global interest in the sphere of culture, an art project by Joaquin Fargas, Robotika, The Nannybot (2019), a similar project Ai-Da Robot Artist (2019) by Aidan Meller and Lucy Seal, and an erotic robot Samantha by Sergio Santos who showed it at Ars Electronica in 2017. It is worth noting intelligent software, such as Cleverbot, Alexa, AARON or Emily Howell and the art project Tomomibot in which artificial intelligence co-creates vocal concerts with the singer Tomomi Adachi. However, in those cases one does not deal with robots' bodies. Therefore, I do not concentrate here on those very interesting technologies used inter alia in art creation.

Let us examine the activities of Ishiguro, an artist, design engineer, professor from Osaka, who creates moving, though not relocating robots which strikingly resemble humans. Geminoids ${ }^{8}$ which have many times been shown at Ars Electronica - Festival for Art, Science and Society (2009-2013), remarkably well imitate some refined movements which could be associated with non-verbal communication. Ishiguro's team put tremendous emphasis on this issue, so they separately concentrated on the arm movements of the robot in their project Alter (2016) which they commented on in the following way: “... even if there's no rhyme or reason to these movements, they're constantly changing following the algorithm they're based on, which imitates the logic of the neuronal circuitry of living creatures." ${ }^{9}$ Geminoids, admittedly, are most often controlled by an outer operator, because not all of them possess the script of artificial intelligence. Still, their bodies are capable of human expression, e.g. through a countenance or a smile which occur due to the actions of an operator sitting in front of a computer and controlling the robot. It is possible owing to cameras and software used to follow the facial movements of the operator and apply them to the robot. Other mentioned small movements of the body also add to the expression. For example, during the Ars Electronica festival, Geminoid HI-1 sitting behind a table made a small, but attention-attracting movement with its foot, which deceptively resembled nervous and/or unconscious behaviour which, in turn, affected the perception of this situation by the conference attendees:

"After all, we perceive stimuli both consciously and unconsciously. When we observe other people, different regions of the human brain are activated. Sensory inputs are automatically compared with familiar human models, which

8 Geminoid F: https://www.youtube.com/watch?v=9q4qwLknKag, https://spectrum.iee.org/ automaton/robotics/humanoids/040310-geminoid-f-hiroshi-ishiguro-unveils-new-smilingfemale-android

9

K. Ogawa, I. Doi, T. Ikegami, H. Ishiguro, Alter, documentation on the website of Ars Electronica 2018: https://ars.electronica.art/error/en/alter/ 
forms the basis of our reactions. Furthermore, these unconscious processes are precisely what induces us to unthinkingly treat an android as if we were dealing with a human being." 10

Other autonomous Geminoids: Kodomoroid and Otonaroid can have a simple conversation, as well as update their content from the web. They are intelligent enough to be capable of working, for example, at Tokyo's National Museum of Emerging Science and Innovation, providing information for visitors. These robots can read fluently and modulate their voices. They can also exhibit facial expressions and arouse interest using their human-like silicon surface alongside with the ability to communicate humanly. ${ }^{11}$

A 20-minute theatrical performance Android-human Theater Sayonara (Good-bye) in 2011 by Oriza Hirata and Hiroshi Ishiguro, in which a woman and a robot play in a scene where the woman who has grown up with the robot since her childhood wishes to get rid of her robotic fellow, which causes the robot to say that it desires to be turned off, is of special interest for me. The audience could talk about their emotions in a questionnaire which we could summarise as follows: "The co-starring of an android and a human makes spectators, even if for a brief moment, start doubting which of the two seems more human-like, and the strange feeling arises that perhaps the robot is more human than humans." 12

There is an interesting question related to the concept of the uncanny valley which emerged in the 1970s, developed by Masahiro Mori. ${ }^{13}$ His research showed that man awaits and responds to tiny reactions coming from another man and/or a robot, and the lack of such behaviours arouses uncertainty and/ or even fear. In conclusion, the authors said that the more a robot resembles a man, though being deprived of the human character, the more it arouses

10 Comments on Geminoids, Featured Artist: Hiroshi Ishiguro, in Ars Electronica 2009: https:// ars.electronica.art/humannature/featured-science-art/featured-artist-hiroshi-ishiguro. in 2010 Ishiguro built another robot called Telenoid which was not a fully anthropomorphic robot, but looked like a several-centimetre-tall doll with visible cables used to control it. It turned out that by participating in a debate with the Telenoid, using the words of the operator who remotely controlled it, the spectators became significantly involved and, in the course of the conversation, embraced the Telenoid showing emotional engagement.

11 Y. Kageyama, Woman or machine? New robots look creepily human, Phys.org, June 2014: https://www.google.com/url? sa=t\&rct=j\&q=\&esrc=s\&source=web\&cd=8\&ved=2ahUKEwjjgqHUxLDoAhXoAxAIHQilDG0QFjAHegQIARAB\&url=https\%3A\%2F\%2Fphys.org\%2Fpdf322800864.pdf\&usg=AOvVaw0tT85G3_FDN50jRuFtngK8

12 A website devoted to Kyoto Experiment (the premiere performance of Android-human Theater Sayonara): https://kyoto-ex.jp/home/eng/archive/2011_hirata_ishiguro/

13 M. Mori, The Uncanny Valley: The Original Essay by Masahiro Mori, transl. K. F. MacDorman, N. Kageki), IEEE Spectrum 2012: https://spectrum.iee.org/automaton/robotics/humanoids/the-uncanny-valley 
fear by its haunting behaviour and it shall not gain acceptance from the audience. Four decades later we encounter similar questions and polemics with this statement. The conclusions from the research show that these negative effects disappear in improved versions of the robots. ${ }^{14}$ Engineers building the above-mentioned robot Alter ${ }^{15}$ took into account significant similarities of the tiny movements to human behaviours, considering their complexity. They even removed the surface of the robot, revealing the content under the chest of Alter, for the purpose of preserving the impression that its movements resemble the natural movements of man. ${ }^{16}$ It may be true that the uncanny valley is a historical concept coming from the times when anthropomorphic robots were not appreciated. It may have been caused by their imperfections and novelty, as well as a lack of imagination that could benefit such technology. We need to take into consideration the mentality of the recipients who were surprised by such artefacts. Modern achievements in the creation and building of anthropomorphic robots provide grounds to claim that it is possible that anthropomorphic robots which approach the ideal in terms of their form, intelligence and mentality, are much awaited and they shall play a variety of roles in public and family lives.

The problems outlined above are to be linked with the much-debated issue of emotion-like and empathic reactions of anthropomorphic robots. These refer to the socialisation of such robots in everyday life or to more specific reactions to types of behaviours which are normally destined for other people or animals, which may involve liking and/or even love. As it turns out, the increasing acceptance of such robots is due to their human appearance, ability of language communication and facial expressions including those showing pain and suffering. The robot Affetto can express the abovementioned emotions. Ultimately, you may conclude that anthropomorphic robots shall be more accepted by people than those which do not resemble humans:

"Robots that are human-like in both appearance and behaviour, are treated less harshly than machine-like robots. This could be related to higher empathy

14 F. Pollick, In Search of the Uncanny Valley, in: P. Daras, O. M. Ibarra (eds.), User Centric Media, Springer 2010, pp. 73-74: https://www.researchgate.net/publication/221435657_ In_Search_of_the_Uncanny_Valley and J. L. Samuel, Company from the Uncanny Valley: A Psychological Perspective on Social Robots, Anthropomorphism and the Introduction of Robots to Society, "Ethics in Progress - Research Journal", Vol. 10 (2), 2019, pp. 12-13, DOI:10.14746/ eip.2019.2.2: https://pressto.amu.edu.pl/index.php/eip/article/view/19969/19643

15 Documentation of the robot Alter: https://artsandculture.google.com/asset/alter-alter-production-team\%EF\%BC\%88hiroshi-ishiguro-takashi-ikegami-kohei-ogawa-itsuki-doi-hirokikojima-atsushi-masumori\%EF\%BC\%89/cgFN86bZHprrOg

16 H. Leopoldseder, Ch. Schopf, G. Stocker (eds.), CyberArts 2018 - International Compendium. Prix Ars Electronica - Starts Prize, Hatje Cants Verlag, Berlin 2018, p. 57: https://ars. electronica.art/error/files/2018/08/CyberArts2018.pdf 
expressed towards anthropomorphic robots, as their appearance and behaviour can facilitate the process of relating to them. A robot that expresses 'emotions' could also be treated as more human-like, which could change people's behaviour." 17

The problems of mimetisation in terms of human physicality and mentality has gained more significance with regard to the increased ability of robots to identify feelings, although robots are incapable of returning the feelings apart from programmed reactions which seem emotionally real. You could claim that the value of their existence and interaction with man is more important than their incapacity to feel the way humans do. The social aspect of their existence, i.e. the co-existence of robots and people may become more and more significant, and ultimately lead to starting close relationships between humans and robots. Thus, the claim that an intelligent robot is only a specific type of an object which should not be treated as man, particularly in terms of emotionality, does not have to be convincing in practice.

A good example of a widely renowned and accepted anthropomorphic robot is Sophia - a robotic woman who has made a career all over the world and has been given the citizenship of Saudi Arabia, which is strikingly unusual because women in that country were granted full voting rights as late as in 2015. Sophia has given many interviews, e.g. it talked to the Secretary-General of the United Nations. This example may show that this type of a robot combines discrete movements, facial expressions and behaviours which we could call reflective and link them with the mental capacity which Sophia acquires while learning in interactions with people and in similar situations, drawing on the information from the web. Its electronic psyche revealing human competencies and broad knowledge in many areas has become the subject of interest. Sophia could even surprise us by telling jokes, which makes people accept or even admire the robot. You could even claim that it belongs to the embodied commonplace of the woman. Though it arouses a lot of interest, there is no effect of the uncanny valley and you may expect that other similar robots will be more like human beings, and perhaps will exceed their capabilities in many respects.

Another example which is worth mentioning is the artwork Robotika, The Nannybot (2019) by Joaquin Fargas. It is a babysitter, a caring robot in a sitting position, holding a child, recorded in film documentation. This robot is caringly turning its head and casting LED light on the face while talking:

17 J. Złotowski, D. Proudfoot, K. Yogeeswaran, Ch. Bartneck, Anthropomorphism: Opportunities and Challenges in Human-Robot Interaction, in: Springer (CrossMark), "International Journal of Social Robotics”, 7(3) June 2014, p. 349, DOI: 10.1007/s12369-014-0267-6: https:// link.springer.com/article/10.1007/s12369-014-0267-6 
"At the same time, there' 11 be an interactive artistic installation in which the human baby will be replaced by a doll that can be operated by the public. Robotika's sensors will determine the child's situation. If the baby cries, Robotika will try to calm him with soft moves, vibrations and songs. If she can't calm him, she '1l call his biological mother." 18

Another document shows the babysitter singing a lullaby, moving its shoulders and knees, using recorded voice (e.g. the voice of the biological mother), and measuring the temperature and humidity of the child with uninterrupted reactions to its movements. This example introduces a discourse on the possibility of advanced decision-making by the robot. The fact that the robot is given responsibility for the child means that it is trustworthy and autonomous. One must be strongly convinced about its perfect actions and accept it as a partner which is capable of dealing with a given situation. However, a question can be posed whether a senseless machine could manage the multi-faceted behaviour of a child, which is important in this case because of the acceptance of the scope of the robot's autonomy. Let us look at this case from an opposite point of view and consider why we need to proceed in this way as we deal with a perfect imitation of motherly and fatherly behaviours, or even overprotectiveness? There is another issue which may seem sensitive. It refers to our usual acceptance of and trust in human carers, though this is not always the case. Facing the choice between a human and a robot, it is especially important to rationalise that caring is here programmed up to the limitations of human imagination, just like prudence, the precision of actions and, which is more important, the lack of negative reactions. Thus, in the future, it is probable that the use of robots in caring for a child and its education shall not only be acceptable, but will become part of parenthood. Contact with the robot will probably evoke positive emotions, as well as involve caring gestures, friendly sounds, caring for the child during illness, safety and having fun, etc. What I claim to be of utter importance is that there is a need to exclude any aggression or intentionally negative actions, based on research on other robots, including educational robots ${ }^{19}$ which interact with children. You could assume that a child will get accustomed to or may even like a robot such as Robotika.

18 Website of Joaquin Fargas: http://webcache.googleusercontent.com/search?q=cache:tAtL44yT2h0J:www.joaquinfargas.com/en/wp-content/uploads/2016/02/robotikaingles. $\mathrm{pdf}+\& \mathrm{~cd}=2 \& \mathrm{hl}=\mathrm{pl} \& \mathrm{ct}=\mathrm{clnk} \& \mathrm{gl}=\mathrm{pl} \& \mathrm{client}=$ firefox-b-d

19 A. Güneysu, I. Karatas, B. Indurkhya, O. Așık, Attitudes of Children Towards Dancing Robot Nao: A Kindergarten Observation, International Conference on Social Robotics 2013 "Taking Care of Each Other: Synchronisation and Reciprocity for Social Companion Robots", Bristol, UK 2013: https://www.researchgate.net/publication/259639226_Attitudes_of_Children_Towards_Dancing_Robot_Nao_A_Kindergarden_Observation 
You could pose the questions whether such a substitution of roles which limits or even eliminates a child's contact with parents could lead to new emotional education. Or, perhaps, a child's contact with parents is always so necessary that it can hardly be replaced by a caring robot? If such a change occurs, could it lead to the emergence of problems in our relationships with other people and a tendency to prefer developing contact with robots? It is not easy to answer the questions above and any attempt to do it may incite controversies, as well as implies the need to conduct interdisciplinary research. However, the apparent development of robotic engineering and human mentality, which is becoming more accepting of such robots, will surely result in the development of such phenomena.

A particularly interesting phenomenon connected with open criticism of artificial intelligence is a series of artworks by Ken Feingold, with such robotic installations as Sinking Feeling (2001), What If (2001), If/Then (2001), The Animal, Vegetable, Mineralness of Everything (2004), You (2004) and Hell (2013). There, the spectator encounters robots which are humanised in a variety of ways. Most of them have the form of heads, e.g. in Sinking Feeling, where a head in a flowerpot is in dialogue with the recipient, or in other works where heads talk to each other. These artworks show that, at a first glance, a meaningful dialogue with artificial intelligence only involves careful selection of words on its part, but statements made by the robot have no deeper meaning and they only endlessly touch one theme which is interesting at a given moment:

"The art viewer, then, experiences these works as a kind of theater in which the earlier described temporal flow finds temporary/illusory nodal points of narrative when the computers appear to understand each other. But, ultimately, there is no one there, only the traces that lead back to the play between intention, randomness and rules deep within the works "running" the software. Although in appearance it is akin to mental functioning, their proclaimed selfawareness and verbal reference to their internal affective states is no more real than the fruit in a still life." 20

However, the criticism mentioned above contains an element of nostalgia coming from the consciousness of limitations and incapacity to achieve the goal, i.e. human-like algorithmic awareness. One needs to consider that these artworks and views which have arisen in connection with them are of historical value, and that the development of artificial intelligence has led to ambiguity, as well as to some assertions or questions concerning the ways of understan-

20 K. Feingold, Figures of Speech, in: R. Kluszczyński (ed.), Ken Feingold - Figures of Speech, "Art+Science Meeting", Łaźnia Centre for Contemporary Art, Gdańsk 2014, p. 34: https:// www.academia.edu/19067518/Ken_Feingold_Figures_of_Speech_Ken_Feingold_Figury_ mowy 
ding and naming the reactions of artificial intelligence which derive from the processes of deep learning and their broad autonomy. We should also discuss the difference between biological and non-biological processing of information, which makes us talk about the similarities and parables concerning human-like and programmed reactions of a robot, rather than about their identification with the reactions of man. This commonplace manifests itself in the idealisation of the human character and not in being a perfect man.

The issue of the algorithmic psyche is a sensitive topic because it triggers ambivalent feelings and views concerning the scope of acceptance and attitudes towards the robot, especially one whose behaviour is similar to conscious reactions. Let us look at a specific diptych consisting of two artworks: Blind Robot (2011) by Louis-Philippe Demers and SEER: Simulative Emotional Expression Robot (2018) by Takayuki Todo. Both robots are only partly similar to human beings, because the first one is just a headless torso with arms and the other one is a small female head. Despite their unusual appearance, both robots can be intriguing and may easily engage viewers in the process of aesthetic experience. Blind Robot performs a series of gestures, delicately touching a spectator sitting in front of it, causing a pleasant feeling resulting from the physical contact, which may appear to be something unknown and/or awaited, and received with pleasure due to one's participation in the reception. I may add that this touch is pleasant and could prompt one to engage in further interaction. It is sufficient to move away from the silicon hand and it will also move a significant distance away, only to come back to the spectator after several dozen seconds. This ensures the sense of safety and increases confidence. The other of the two robots mentioned above is a several-centimetre-tall head made of white plastic material using a technique similar to 3D printing, which allows it to mimic reactions to the viewer by moving its eyes, eyebrows and through small movements of the face. ${ }^{21}$ The facial expressions of the small head which possesses archetypal female traits include surprise and impatience. The interaction consisted in setting up non-verbal contact through, for example, the robot's constant observation of a human. Both robots attracted viewers' attention with their human-like behaviour. Blind Robot made tempting gestures and delicate arms movements, while SEER confidently mimicked facial expressions. In this case, both robots were only partially like humans. Nevertheless, they were ca-

21 Nexi MDS - Mobile, Dexterous, Social (2008), created by Cynthie Breazeal from Media Arts and Sciences, Personal Robots Group, MIT Media Lab (a new version of Kismet (1990) and the robot Mertz (2008) by Lijin Aryanandy and Jeff Weber from MIT Media Lab were representative of the first robots whose creators focused on the facial expression. All of them could have a conversation with a human and reacted by moving their heads, eyes, eyebrows, mouth and/or ears (Nexi also used its arms). 
pable of human-like, recognisable and magnetic expressions due to which they arouse interest and, perhaps, set up an unforgettable experience.

Another anthropomorphic robot is the art robot Ai-Da Robot Artist (2019) built by Aidan Meller and Lucy Seal. Here we deal with the robot itself, i.e. the fruit of collaboration between artists and engineers, and its ability to create art. This art robot with a female look paints portraits and abstractions, which prompts us to pose questions concerning, for example, subjectivity and creative personality.

"She is not alive, but she is a persona that we relate and respond to. [...] Ai-Da, the machine with AI capacities, highlights those tensions: is she an artist in her own right? Is she an artist's alter ego? Is she an avatar, or a fictional character? All these options bring powerfully to the forefront the complexity of our interacting digital and physical worlds and the masked identities we can assume in both." 22

This robot can have sensible conversations and, as it is suitably programmed, it gives an impression of conscious reactions that may become more and more significant with the development of robotic culture, evolving into a sense of partnership. This is an example of a robot which creates art, so a question about the joint creation of culture by robots and humans arises and becomes significant. The first sold picture, Portrait of Edmond Belamy, painted by another representative of artificial intelligence - GAN (Generative Adversarial Network) may confirm this. This picture was sold in an auction at the Christie's in New York for 432,500 dollars. Such an institutional confirmation is one of many cases where artificial intelligence creates art which may be exhibited, sold and collected. ${ }^{23}$

Another issue for debates which are linked with creating and absorbing anthropomorphic robots into the human world, is their assimilation which may result in establishing their position in the human society and the human world. It may become more important than the work which robots perform replacing humans. Having in mind that we may deal with a variety of robots for different purposes, e.g. social or therapeutic ones to set up close relationships with humans, we may not exclude that an intelligent and beautiful anthropomorphic robot could fulfil the emotional needs of a human.

22 The quotation comes from the website "Ai-da Robot, Artificial Intelligence in Art": https:// www.ai-darobot.com/jointhemovement. A short description of the robot may be found in H. Leopoldseder, Ch. Schopf, G. Stocker (eds.), Out of the Box - The Midlife Crisis of the Digital Revolution, Hatje Cants Verlag, Berlin 2019, p. 101: https://ars.electronica.art/outofthebox/files/2019/08/festival2019.pdf

23 P.Tresset,O.Deussen,ArtisticallySkilledEmbodiedAgents, GoldsmithsUniversityofLondon, 2014: http://doc.gold.ac.uk/ $\sim$ ma701pt/patricktresset/wp-content/uploads/2015/03/Tresset_27 0467.pdf 
In the history of art, it was a common practice to show the dignity of man and express the beauty and perfection of the human body. Modern technology with its visionary practice of artists and the skills of engineers may lead to the creation of a robotic picture of the human and accomplish the dreams of artists that originated even in antiquity.

\section{BIBLIOGRAPHY:}

Aristotle, Poetics, trans. Ingram Bywater (1962), Oxford Press.

Bishop Laura, Maris Anouk, Dogramadzi Sanja, Zook Nancy (2019) Social robots: The influence of human and robot characteristics on acceptance, "Paladyn - Journal of Behavioral Robotics" Vol. 10/1, 2019, pp. 346-358, DOI: https://doi.org/10.1515/pjbr-2019-0028

Epley Nicholas, Waytz Adam, Cacioppo John (2007) On seeing human: a three-factor theory of anthropomorphism, "Psychological Review", Vol. 114 (4), 2007, pp. 864-886, doi: 10.1037/0033295X.114.4.864: https://www.academia.edu/4851371/On_Seeing_Human_A_Three-Factor_Theory_of_Anthropomorphism

Feingold Ken (2014), Figures of Speech, [in:] R. Kluszczyński (ed.), Ken Feingold - Figures of Speech, "Art+Science Meeting”, Łaźnia Centre for Contemporary Art, Gdańsk, pp. 24-35: https://www.academia.edu/19067518/Ken_Feingold_Figures_of_Speech_Ken_Feingold_Figury_mowy

Güneysu Arzu, Karatas Iclal, Indurkhya Bipin, Aşık Okan (2010) Attitudes of Children Towards Dancing Robot Nao: A Kindergarten Observation, International Conference on Social Robotics 2013: "Taking Care of Each Other: Synchronisation and Reciprocity for Social Companion Robots", UK: https://www.researchgate.net/publication/259639226_Attitudes_of_Children_Towards_Dancing_Robot_Nao_A_Kindergarden_Observation

Kageyama Yuri (2014) Woman or machine? New robots look creepily human, "Phys.org", June 2014: https://www.google.com/url?sa=t\&rct=j\&q=\&esrc=s\&source=web\&cd=8\&ved=2ahUKEwjjgq HUxLDoAhXoAxAIHQilDG0QFjAHegQIARAB\&url=https\%3A\%2F\%2Fphys.org\%2Fpdf 322800864.pdf\&usg=AOvVaw0tT85G3_FDN50jRuFtngK8

Leopoldseder Hannes, Schopf Christine, Stocker Gerfried (eds.) (2018) CyberArts 2018 - International Compendium. Prix Ars Electronica - Starts Prize, Hatje Cants Verlag, Berlin: https://ars. electronica.art/error/files/2018/08/CyberArts2018.pdf

Leopoldseder Hannes, Schopf Christine, Stocker Gerfried (eds.) (2019) Out of the Box - The Midlife Crisis of the Digital Revolution, Hatje Cants Verlag, Berlin: https://ars.electronica.art/outofthebox/files/2019/08/festival2019.pdf

Mori Masahiro (2012) The Uncanny Valley: The Original Essay by Masahiro Mori, transl. K. F. MacDorman, Norri Kageki, IEEE Spectrum: https://spectrum.ieee.org/automaton/robotics/humanoids/the-uncanny-valley 
Myoo Sidey (2019) Creative Robots, in: Nataša Janković, Boško Drobnjak and Marko Nikolić (eds.), "Proceedings of the 21st International Congress of Aesthetics, Possible Worlds of Contemporary Aesthetics: Aesthetics Between History, Geography and Media”, University of Belgrad, Belgrad, pp. 1145-1149: http://www.sideymyoo.art.pl/wp-content/uploads/2019/11/SideyMyoo_Creative-Robots.pdf

Ogawa Kohei, Doi Itsuki, Ikegami Takashi, Ishiguro Hiroshi (2018) Alter, Ars Electronica: https://ars.electronica.art/error/en/alter/

Pollick Frank (2010) In Search of the Uncanny Valley, [in:] P. Daras, O. Mayora Ibarra (eds.), User Centric Media, Springer, pp. 69-78, DOI: DOI: 10.1007/978-3-642-12630-7_8: https://www. researchgate.net/publication/221435657_In_Search_of_the_Uncanny_Valley

Samuel Janina Luise (2019) Company from the Uncanny Valley: A Psychological Perspective on Social Robots, Anthropomorphism and the Introduction of Robots to Society, "Ethics in Progress Research Journal”, Vol. 10 (2), pp. 8-26, DOI:10.14746/eip.2019.2.2: https://pressto.amu.edu. pl/index.php/eip/article/view/19969/19643

Tresset Patrick, Deussen Oliver (2014) Artistically Skilled Embodied Agents, Goldsmiths University of London: http://doc.gold.ac.uk/ ${ }^{\sim}$ ma701pt/patricktresset/wp-content/uploads/2015/03/ Tresset_270467.pdf

Wójtowicz Ewa (2014) Writing Personalities. Art Vis-a-vis Artificial Intelligence - Ken Feingold's "Figures of Speech", in: R. Kluszczyński (ed.), Ken Feingold - Figures of Speech, "Art+Science Meeting", Łaźnia Centre for Contemporary Art, Gdańsk, pp. 76-107: https://www.academia. edu/19067518/Ken_Feingold_Figures_of_Speech_Ken_Feingold_Figury_mowy

Złotowski Jakub, Proudfoot Diane, Yogeeswaran Kumar, Bartneck Christoph (2014) Anthropomorphism: Opportunities and Challenges in Human-Robot Interaction, [in:] Springer (CrossMark), "International Journal of Social Robotics", 7(3) June, pp. 347-360, DOI: 10.1007/s12369-0140267-6: https://link.springer.com/article/10.1007/s12369-014-0267-6

Websites:

Ai-da Robot:

https://www.ai-darobot.com/jointhemovement

AIArtists.org:

https://aiartists.org/

SingularityHub:

https://singularityhub.com/2019/06/17/the-rise-of-ai-art-and-what-it-means-for-human-creativity/

Engineeredarts:

https://www.engineeredarts.co.uk/

Cloudpainter:

http://www.cloudpainter.com/

Geminoids created by H. Ishiguro:

http://www.geminoid.jp/en/index.html 
Kyoto Experiment Android-human Theater Sayonara:

https://kyoto-ex.jp/home/eng/archive/2011_hirata_ishiguro/

Joaquin Fargasa:

http://webcache.googleusercontent.com/search?q=cache:tAtL44yT2h0J:www.joaquinfargas. com/en/wp-content/uploads/2016/02/robotikaingles.pdf $+\& c d=2 \& h l=p l \& c t=c l n k \& g l=p l \& c l i e n-$ $\mathrm{t}=$ firefox-b-d

\section{TOPOS CZKOWIEKA W EPOCE ANTROPOMORFICZNYCH, INTELIGENTNYCH ROBOTÓW (streszczenie)}

Celem artykułu jest zaprezentowanie toposu człowieka w nawiązaniu do teorii mimesis na tle analizy współczesnych przykładów antropomorficznych, inteligentnych robotów. Uwzględnione są dwie warstwy analizy: pierwsza, wiążąca się z upodabnianiem takich robotów do wyidealizowanego ludzkiego ciała oraz druga, w której uwzględnia się podobieństwo powyższych robotów do człowieka w warstwie mentalnej, co wiąże się z zagadnieniem sztucznej inteligencji. Większość zaprezentowanych przykładów pochodzi ze świata sztuki, będąc efektem interdyscyplinarnej współpracy artystów z inżynierami. Artykuł zawiera analizę porównawczą, jak również część treści wynika z obserwacji uczestniczącej, co wiąże się w szeregu przypadkach z kontaktem autora tekstu z prezentowanymi inteligentnymi robotami.

Słowa kluczowe: topos człowieka, antropomorficzny robot, ideał cielesności, sztuczna inteligencja, sztuka nowych mediów

Sidey Myoo is a scientific pseudonym which comes from the net name that was adopted by prof. dr hab. Michał Ostrowicki in 2007, in Second Life. Sidey Myoo is a philosopher, he works at the Department of Aesthetics at the Institute of Philosophy of the Jagiellonian University and at the Department of Theory of Media Art of the Faculty of Intermedia in Fine Arts in Kraków. He is interested in aesthetics treated as a theory of art, mainly in relation to contemporary art. In 2006, he used the notion of virtual realis (later: electronic realis) which has become a basis for ontoelectronics, i.e. ontology focused on the analysis of electronic reality treated as a sphere of being. In 2007 he founded the Academia Electronica (www.academia-electronica.net) - a non-institutionalized part of the Jagiellonian University based on the model of university in the electronic environment in Second Life, where official academic courses are held and conference presentations are given. 